\title{
Die isolasie en identifisering van Penicillium spp. met potensiële fosfaatoplossingsaktiwiteit in landbou-omgewings
}

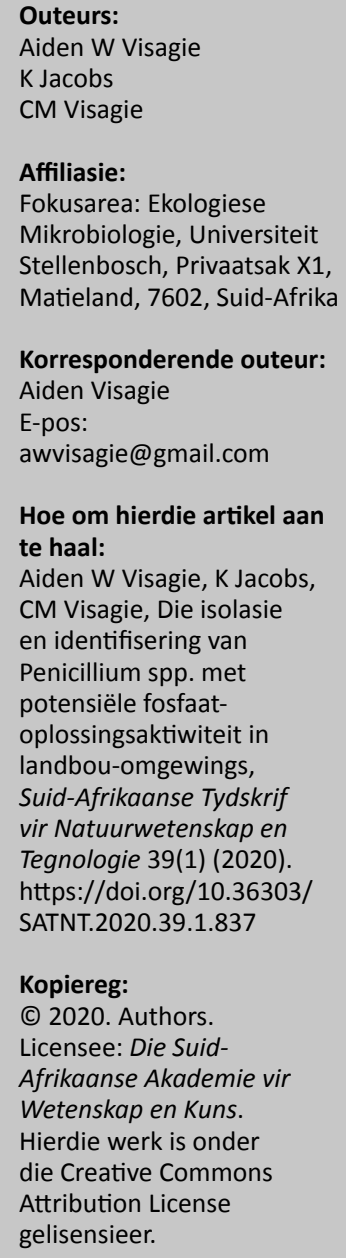

Korresponderende outeur: Aiden Visagie

\begin{abstract}
Isolation and identification of Penicillium spp. with potential phosphate solubilistion activity from agricultural environments: This project investigated Penicillium species diversity in agricultural environments as well as the potential phosphate solubilisation activity of the isolated Penicillium strains. This genus has played a vital role in human history, with the most famous being the production of the antibiotic Penicillin. Thus, understanding the diversity of this genus is of great interest and importance.
\end{abstract}

Hierdie projek fokus op die isolasie en identifisering van spesies van Penicillium in landbouomgewings. Spesies in die genus Penicillium is van groot sosio-ekonomiese belang en speel 'n belangrike rol in verskeie aspekte van die mens. Die antibiotikum penisillien is moontlik die bekendste toepassing van hierdie groep. Die impak van hierdie organismes is nie net beperk tot antibiotikumproduksie nie, en die rol van hierdie spesies, in beide die omgewing en in menslike aktiwiteite kan nie oorbeklemtoon word nie. Lede van hierdie genus is bekend as voor- en na-oes patogene, sowel as in die produksie van verskeie gefermenteerde voedselprodukte, insluitend verskillende tipes kaas en gefermenteerde wors. In vorige studies is aangetoon dat Suid-Afrika ' $n$ kern van Penicillium diversiteit is, met ' $n$ beduidende groep van die Penicillium spesies wat vanuit die grond geïsoleer is. Voor die volle omvang van die diversiteit binne hierdie groep verstaan kan word, moet nog heelwat navorsing op spesies in die groep gedoen word. ' $n$ Ander aspek van hierdie groep is dat hulle tot die prosesse in die grondomgewing bydra. Baie min is bekend oor die funksie van hierdie groep organismes, spesifiek vir koring en mielies. Koringproduserende gebiede in Suid-Afrika toon 'n beduidende verskil tussen die verwagte opbrengs, gebaseer op voedingstof- en kunsmisinsette, en die werklike opbrengs wat behaal word. Hierdie gaping is vermoedelik as gevolg van die gebrek aan beskikbare fosfor in landbougrond. Tot $98 \%$ van die fosfor in die grond is anorganies, en dus nie vir opname deur plante beskikbaar nie. Hierdie studie fokus dus op die diversiteit van Penicillium spesies in landbouomgewings. Die fokus van hierdie studie is nie net op die isolasie en identifisering van hierdie spesies nie, maar dit ondersoek ook die stamme vir moontlike nuttige funksies in grondomgewings, soos hul vermoë om fosfaat op te los sodat dit vir opname deur plante beskikbaar is. In vorige studies is aangetoon dat hierdie aktiwiteit 'n positiewe effek op plantegroei kan hê. Ander plantegroeibevorderings-aktiwiteite (PGA) is waargeneem in verskeie Penicillium spesies, insluitend die vrystelling van verbindings soos gibberellien, jasmoniensuur en salisielsuur. 'n Verskeidenheid gebiede is gekies om monsters te neem, wat verskeie grondtipes, sowel as landboupraktyke insluit. Hierdie gebiede is histories fynbosgebiede wat na landbouverbouing omgeskakel is. In ag genome dat Penicillium spesies in fynbosgronde baie divers is, kan die afleiding gemaak word dat dieselfde vir landbougrond sal geld. Die voorlopige resultate van hierdie studie dui op 'n beduidende spesiesdiversiteit, insluitend verskeie potensiële nuwe spesies, sowel as 'n paar skaars spesies, wat in hierdie gronde aanwesig is.

Nota: 'n Seleksie van referaatopsommings: Studentesimposium in die Natuurwetenskappe, 31 Oktober - 1 November 2019 , Universiteit van die Vrystaat. Reëlingskomitee: Prof Rudi Pretorius (Departement Geografie, Universiteit van Suid-Afrika); Dr Hertzog Bisset (Suid-Afrikaanse Kernenergie-korporasie; Dr Ernie Langner (Departement Chemie, Universiteit van die Vrystaat) en Dr Wynand Nel (Departement Rekenaarwetenskap en Informatika, Universiteit van die Vrystaat). 